\title{
«Заспівати свою пісню на своім подвірю»- достоменніст простору/достоменніст в просторі
}

\begin{abstract}
Abstrakt
„Zaśpiewać swoją pieśń na swoim podwórzu” - tożsamość (w) przestrzeni W artykule ujęte zostały kwestie dynamicznej relacji przestrzenno-tożsamościowej w kontekście destrukcji łemkowskiej przestrzeni etnicznej po wysiedleniach lat 1945-1947. W pierwszej części nakreślone zostało tekstualne wyrażanie się symbiozy, konsolidowania łemkowskiego świata wspólnotowego przez wartości i symbole przestrzenno-pejzażowe, mające cechy archetypiczne. Następnie rozpoznany i wskazany został mechanizm mitu reinwencyjnego, który dąży do ocalenia mocy przestrzeni ojczystej poprzez skontrastowanie jej z przestrzenią obcą z zastosowaniem podziału sacrum-profanum. Powolne wyczerpywanie się tego mechanizmu w świecie odczarowanym wprowadza do symbolicznego uniwersum coraz więcej obrazów przestrzeni pragmatycznej. Mechanizm mitu uaktywnia się natomiast w rytualnej migracji kolistej, która łączy rozbity świat łemkowski poprzez celebrowanie dorocznych rytuałów/ świąt wspólnotowych ustanawiających nowe sensy przestrzenne. Termin "nowe” nie oznacza ich oderwania od tożsamości przestrzeni i tożsamości przestrzennej bazowej dla łemkowskiej podmiotowości. W części drugiej zasygnalizowany został wpływ czynnika przestrzennego na tożsamość językową Łemków. W oparciu o dane statystyczne, korzystanie $\mathrm{z}$ praw językowych oraz zaobserwowane postawy i praktyki językowe wysunięta została teza o zasilaniu przez rodzime wartości przestrzenne mechanizmów i działań rewitalizacyjnych w zakresie języka łemkowskiego.
\end{abstract}


Słowa kluczowe: przestrzeń etniczna, mit reinwencyjny, migracja, Łemkowie, język łemkowski

\begin{abstract}
“To Sing Your Song in Your Backyard": Identity in Space/ Space Identity The article deals with the dynamic spatial and identity relationship in the context of the destruction of the Lemko ethnic space after their deportations in the years 1945-1947. The first part of the article outlines the textual expression of symbiosis, the consolidation of the Lemko community world through spatial and landscape values and symbols with archetypal features. Then, the mechanism of the reinvention myth is identified and indicated, which aims to save the power of the native space by contrasting it with the foreign space using the sacred-profane division. The slow depletion of this mechanism in the disenchanted world introduces more and more images of pragmatic space into the symbolic universe. The mechanism of the myth, on the other hand, is activated in the ritual circular migration that connects the shattered Lemko world by celebrating annual community rituals / holidays establishing new spatial meanings. The concept of newness does not mean that they are detached from the identity of space and the spatial identity that is the basis for Lemko subjectivity. The second part of the work presents the influence of the spatial factor on the linguistic identity of the Lemkos. Based on statistical data, the use of language rules and the observed linguistic attitudes and practices, a thesis is put forward that native spatial values feed the mechanisms and activities of revitalization in the Lemko language.
\end{abstract}

Keywords: ethnic space, reinvention myth, migration, Lemkos, Lemko language

\title{
Просторовы вартости і значыня
}

Повязаня достоменности з простором єст на тілько очывидне, же не вымагат специяльной аргументациі. Ограничу ся прото вступні до пару лем постережынь загального характеру. Феноменологія выакцентувала реляцийный характер простору інтерпретуючы го як егзистенцийну реляцию:

Простір жытя єст субєктывный, зрелятывізуваный і емоцийні забарвленый. Выполненый все окрисленыма значынями і змістами. Приналежыт 
до єдиниц, культур і епох. Його ріжнородніст єст невычерпана. Не даст ся го зредукувати до парох теоретычных тем ани змінити в дашто єднородне, формальні зрівнане. Не даст ся обдерти зо свойой субєктывности ани релятывности. [...] Релятывніст понятя простору єст адже в феноменологіi довершана през одкликаня ся до підметовых пережывань, в якых простір пережываня ся появлят (Buczyńska-Garewicz 2006, 11, пер. О. Д-Ф).

На грунті соспільных наук звертат ся увагу на просторовы вартости, што сут спільным добром окрисленых груп, складником вызнаваной през них системы вартости, в рамах якой отримуют своє назначыня змістове і сутьове. Спричыняют они способы просторового поведіня груп і єдиниц в іх обсягу. Прото в просторі вміщаны сут всякы символі, уявліня, стереотыпы і образы, якы формуют групову достоменніст. Традицийні простір узнаваный был за конститутывный елемент етнічности a етнічна достоменніст выражала ся просторово. В часах глобалізациі, коли переміщаня ся, міграциі, перениканя, переплыв культуровых вартости спричыняют явиско назване «выкореніньом» (Weil 1983; Lompart 2010), простір стає ся єдным з елементів негоциюваных в рамах етнічности і ма дискурсивны приметы. Хоц дале обовязує окрисляня етнічных груп/ спільнот як територийных, то штораз рідше односит ся то до реальні спільні заниманых земель, а барже до психічных постав, часто розвиваных на мітычным компоненті (Smith 1991). 3 просторовыма категориями - на што звернул особливу увагу I-Фу Туан (Tuan 1977), розсмотрюючы напятя медже «простором» а «місцьом»- вяже ся дилема погоджыня двох основных чловечых потреб: потребы безпекы і потребы свободы/ вандруваня. Коли єднак вандруваня/ міграция проходит не з власной волі і потребы, лем єст вымушена, не маме до діла зо свободом, лем з насильством описуваным при схоснуваню такых понять як dislocation (переміщыня), displacement (позбавліня місця), enracinement (выкореніня). То сут понятя повязаны так з контекстом колонізуваня в значыню завлащаня простору през домінуючый дискурс, як і з полученыма 3 колонізуваньом выселінями маючыма довести до колонізациі/ асиміляциі. Спричыняют они травму (макротравму) - спільнотове досвідчыня конденсуюче в комунікацийній, а з часом в культуровій памяти образы стану загрожыня тяглости групы (Bokszański 1999).

Лемківскє спільнотове/ культурове розпознаваня ся в просторі односит ся безпосередньо, як знаме, до такого же досвідчыня. Цілю той статі 
єст накрислити декотры наслідства політычного насильства в обшыри просторовой достоменности Лемків.

\section{Міфічна реінвенция - міґрацийна достоменніст}

Як уж єм вказувала деінде (Дуць-Файфер 2017), вызваньом, з якым мусит собі порадити спільнота по переселіню, єст сотворіня реінвенцийного міфу, оповіджыня, представліня і зрозумліня себе по переміні, на ново. В лемківскій реінвенциі простір грат основну ролю. Тото, што нарушыли выселіня, то предо вшыткым сильне, органічне повязаня люди - корінной спільноты - з земльом, што з нєй «выросла», што в ню «вросла», 3 яком ся «зросла». Тоты органічны, вітальны метафоры осаджены глубоко в фольклоровым одчуваню єдноты цілого космосу інтегруючого ся гу жытю, його роджыню і росніню проти смерти (Bartmiński 1988), сут архетыпічным мотывом лемківской текстуальности од початку єй розвитя. Наганяют наррацию і реторику більшости повязаных з лемківскым символічным універсум текстів. Конденсуют ся в образах гір і люди през них в своім характері, силі, достоінстві уформуваных (чого приміром сут Карпатскы новелі - Поляньскій 1880). Евокуют реторичны звороты:

Бескиде! - съдый Бескиде! ты опасалъ нашу землю, смотришь поважно на жизненныи нивы и долины, на густы боры и просторныи степы, и освъжаешь ихъ своими водами. Не одна уже туча и не одинъ громъ перейшолъ по-надъ твою голову, а ты стоишь все твердо и непоколебимо. Не разъ ты уже засумувався, видячи народъ, на котрый смотришь, въ кровавой нуждъ, - а однакъ ты все веселый, и все зъ весною новая зелень покрывае тебе, новый цвътъ прозябае на тобъ и новая вонь роздаеся отъ тебе. Не диво про тое, що смотрячи на тебе новыми надъями наполняются люди (Тороньскій $1862,57)$.

Поясняют механізмы чловечых діянь, детермінаций, емоций:

Ой, Лемко любитъ свои жбири, и якъ ихъ любитъ! Онъ буде пантрувати по цълой Європъ за кускомъ хлъба, котрого не дораблятся на своемъ грунть, але зароблений кусокъ приходитъ зъъсти на своихъ жбирахъ зъ женомъ и дътми (Астрябъ 1871, ч. 51, 202). 
Сут простором магіi, діяня ріжных сил, буйности жытя, сут базом і грунтом вітальности:

Корови моляться до сонця, що полум'яним сходить маком.

Струнка тополя тонша й тонша, мов дерево ставло б птахом.

Від воза місяць відпрігають Широке, коноплясте небо.

Обвіяна далінь безкрая,

і в сивім димі лісу гребінь.

3 гір яворове листя лине.

Кужіль і півень, і колиска.

Вливається день до долини, мов свіже молоко до миски (Антонич 1967, 160).

Сут базом естетычных дознань красы, гармоніi, своєрідности:

Каменисты пути и потокы рвучы, Березовы дебри и лісы дремучы Кичеры высокы, поляны зелены, Пропастны ростокы, здубы пороснены (Русенко 1945, 147).

На іх основі, з іх спілучастю, жывым спілдіяньом усталят ся етнічны границі «свого»:

Од Тячева, Ужгорода, през Гуменнне, Пряшев, Плынут ку нам милы хмаркы с вісточком од нашых, Идут дале ку Щавниці, през татрянскы турні, През Шляхтову, Білу Воду - гет аж ку Остурні.

А ліс шумит, пісню співат и скухают хмары, О волі, о прошлой славі и о часах старых (Русенко 1945, 148). 
Сутьово тото повязаня народу з простором, зо земльом выразил Петро Мурянка:

[...] do tego, by żył naród, społeczność, rodzina nawet... potrzebne są groby przodków. Potrzebne są rzeka, las, uroczysko. Każde nazwane własnym imieniem, nazywane stuleciami. Trzeba wiedzieć $\mathrm{z}$ dziadka na wnuka, gdzie siać owies, a gdzie pietruszkę, gdzie orać «na skład», a gdzie wyorywać bruzdę, gdzie budować dom, by w czas żywiołu nie spłynął z wodą. Potrzebna jest przeszłość człowieka i ziemi. Razem, tylko razem (Trochanowski 1992, 9-10).

Коли, адже, тота симбіоза, спілжытя, одвічны узлы остают перерваны, заходит деструкция цілости культурового механізму групы. Жебы перетырвати, сохранити достоменніст і дальше розпознавати ся як тота сама, хоц не така сама, спільнота, мусит змінити своі автоідентыфікацийны параметры. Тому як раз служыт реінвенцийный міф. Хоц може ся то здавати парадоксом, лемківска реінвенция доконує ся на базі найбарже нарушеного елементу етнічной достоменности - простору. Текстуальна символізация не лишат той цілком здеструуваной основы розумліня і выражаня себе, не редефініює сути лемківской підметовости на базі інчого вызначника. Механізм саморозумліня і самовыражаня, хоц оперує цілком зміненым материялом, грунтом, хоц мусит міфічні выразити суть той зміны, то функцийні остає тот сам. Дальше доконує ся просторово. В тот спосіб пукніня в достоменности єст засклепляне, хоц не забыте, не «выгоєне», бо в міфі стає ся діючом, операцийном, фурт актывном силом. Синтезом реінвенциі єст, як і в первістным достоменностьовым міфі, простір, але скрайні перетвореный бо охопленый, переникненый повыселенчым автодефініючым лемківску спільноту тавром болю. Апострофа до Бескіду, хоц дале стоіт при основах міфічного розумліня долі бескідского народу (як в приведеным горі тексті Тороньского), то задіяти мусит реінвенцийні, оповісти, што ся стало з том нерозрывном реляцийом, чом она тепер болит:

Бескіде мій

як доля горбатый

як воля міцнійшых

скамянілый 
Болит мя краса твоя

в наймиты взята

на експо світу выставлена

а нам што єй вірно в серцях плекали

без вікы несли

до рівных дни

списами заставлена (Мурянка 1989, 6).

Соткы текстів працуют по выселіню на зрозумілый, спійный, емоцийні і етычні назначеный, поясняючый днешніст міф лемківского простору, зміненой, хоц надале базовой просторовой достоменности. Мусит быти оспіваны, оплаканы біль, смуток, розпука, туга досвідчаны през обі стороны просторово-чловечой єдни.

Як Русины задумали

Лишыти Карпаты,

То природа вся зачала

Жалібно плакати.

В плачу сосны і смерекы,

Плакала ялина

I гу земли ся схылила

Червена калина. [...]

Од хыж рідных пішли Лемкы,

По світі блукали

I лем товды за Бескыдом

Гірко заплакали.

I я плачу-оплакую

Святу Лемковину

Люты врагы замінили

В велику руіну. [...]

Де колиси буйне жытя

Такє красне было,

Там волк выє, кричат совы

Бадыля всьо вкрыло (Жылич 2002, 98-99). 
Мусит быти вказана крайня переміна, метаморфоза землі і люди:

В тот вечер приде до вшыткых Сын Божий. Може задивит ся на землю што перед роками квитла луками квітів, пахла ярцьом і вівсом, што золотили розколысаны берегы бескыдскых шаховниц поля званого царином. Бо-ж царювали там Лемкы і небесны птахы, якы стерегли святынь під блакытным куполом неба.

Не ма гнеска сонця в волосю дівчат і жінок, што жали врожаі, а хресты, якы значыли лемківскій пут - поперевертано, вырвано острыма списами ребра деревяных церкви, проколото іх до глубины серця, аж загмерли голосы дзвонів, замліли од удару, затихли (Грабан 2002, 428).

Гей, нашы Лемкы в Кошаліні

В Зеленій Горі плечы гнут (Русенко 2002).

Росне нове поколіня,

Што Тя не виділо,

Йому сонце верховинскє

Серця не загріло (Горощак 2002, 124).

В опозициі до першого, благородного, міфічного, святого, свойого простору мусит явити ся його заперечыня - чужына, не своя земля. То в однесіню до нєй доконувати ся мусит неустанный, проти штоденности, проти течыню асиміляцийного часу «Віслы», вперто і зо штораз векшым трудом веденый процес реінвенциі, в якым тот простір николи не може перестати быти чужыном. Три основны текстуальны стратегіi наганяют і підтримуют тот процес. Перша діє силом світа зачаруваного, в механізмі міфу, в знакуваню простору полюсами сакрум-профанум:

Моя Лемковино [...]

Далеко од тебе

Бє ся серце моє,

3 мысли мі не зыйдеш николи

Не мож привыкнути,

Тебе позабыти,

Серцю приказати, бо болит! 
Бо пташына в клітці,

Хоц выгоды має,

3 розпачы по стінах бє крылом.

Я, хоц і не в нужді, -

Радости не маю,

Бо нич мі в чужыні не миле (Собин 2002, 128).

Друга стратегія то одчаруваня світа, здистансуваня чужыны, выключыня єй з простору міфу, зведіня єй до моделю простору прагматычного ${ }^{1}$. В тым моделю чужына не може стати ся лемківском земльом, бо єст она земльом ничыйом, простором, якій вшыткы, што в ним жыют, раціональні выкорыстуют до свойой егзистенциі. Лукы служат до пасіня худобы, земля до ораня і сіяня, ліс до позыскуваня дерева або затрудніня ся при його саджыню, дім до мешканя, школа до вчыня, церков до релігійных практык ітд. Так оповідают Лемкы о своім жытю на Заході (бо знакуваня го як чужыны в такій наррациі не єст потрібне ани умотывуване):

Наша осмоособова фамелия впровадила ся до представленой попередньо старой хыжы, на перший позір зближеной своім выглядом до лемківскых хыж, при котрий, недалеко угла, на горбочку находила ся центральна студня.

Ту, при студни, в першы дни прибытя, по нараджыню ся піднимано спільны і особливы децизиі. Перша - як памятаме - дотычыла корыстаня з воды в студни. Потім припомнено, де хто мал замешкати і цілыма родинами пішли обізрити в якых поміщынях приде ся ім мешкати і жыти.

Ден был барз горячий, быдлята были голодны і не хтіли стояти при возах. По обізриню поміщынь в будинках ураджено, жебы худобу понапавати і пустити пасти в поближу забудовы. Діти дадут позір і припильнуют статку, а старшы взяли ся за робіня порядків в заниманых поміщыняах і прирыхтуваня ix до преночуваня. Вечером, по тых і подібных роботах, газдове позганяли худобу до великых стаєн. В каждій фамелиі каждий єй член, ци старший, ци молодший, ци дітина, мал што робити, бо роботы было без міры, а за єдно пополудне зробити ся єй не даст, робит ся тото, што найбарже потрібне - найконечнійше. Обовязком єст подоіти коровы, накормити діти і самому ся пожывити, прекусити хоцбы кавальчык окрайця насушеного

1 Так, як клясивікує простір I-Фу Туан, якій выріжнят три основны тыпы простору: міфічный, прагматычный і абстракцийный або теоретычый (Туан 1987, 29). 
хліба і запити зимном водом зо студні. Шпаргетів в занятых будинках або не было, або были розбурены, чого поправити напрудці ся не даст. Не было де запалити, на чым пригріти ци зварити (Сук 2009, 21).

Przypomniało mi się, na pewno się przypomniało, jak ze dwa lata przed tym żmija gnała za nami dobre sto metrów. To było koło Waranowego mostu. Właściwie to były tylko resztki mostu, same, przegniłe już belki i kilka desek w poprzek. Pociężą nikt już z niego nie korzystał, jedynie przejść $\mathrm{z}$ trudem można było na drugi koniec Szprotawy. Obok mostu, po naszej stronie rzeki usypany był długi kopiec, tak jakby kawałek wału rzecznego. Nie, to nie był wał rzeczny. Takich kopców było we wsi kilka. Jak nam przekazał Palidrab, dawni skrzętni gospodarze - Niemcy oczyszczając pole z perzu, gromadzili go w takie właśnie kopce. W nich lubiły gnieździć się węże [...]. Rzeczonego dnia znaleźliśmy się koło Waranowego mostu - ja z Ładkiem i Dozkiem Morczakami. Uzbrojeni w długie kije postanowiliśmy zbadać kopiec. Wpychaliśmy je to tu, to tam, aż... zafalował gwałtownie długi czarny grzbiet i zaczął szybko pełznąć w naszą stronę. Wzięliśmy nogi za pas [...]. Wrzeszczeliśmy przy tym jak nieboskie stworzenia. Strachu dodawało jeszcze to, że Morczakowa brama była przymknięta, rozumieliśmy, że nie będzie czasu na jej otwieranie (Murianka 2007, 68-69).

Третя стратегія возникат, коли лемківскій простір штораз барже ся одчаровує, коли міфічны механізмы стабілізуваня і усенсовняня світа слабнут, не сут в силі (хоц фурт прібуют) пояснити реальности, в якій рішуча більшіст «выгнаной з раю» спільноты остає на чужыні, хоц могла бы вернути на Лемковину, як то зробила інча, менша част Лемків. Лемківска реінвенция мусит задіяти синергійом прагматычной реальности і міфу. Так західній, як і гірскій, а в гідній мірі тіж украіньскій (в розумліню місц, де мешкают выселены Лемкы) просторы стают ся дискурсивны - выполняют ся діянями, програмами, етнічном, культуровом діяльністю, осягнінями, подіями, річницями ітп. Піддаваны сут оціні, конкуруют зо собом, дискутує ся о них, стремлят они гу модерности. Тратит ся в них міфічне і єднозначне сакрум/ своє - профанум/ чуже.

Ци в такым сфрагментуваным світі може іщы діяти міф лемківской єдни, просторово усенсовненый, маючый тырвалы пункты і місця ненарушены? Адже здиягнозувати мож і днес діючу стратегічну силу лемківской реінвенциі, яка вытварят гыбридный механізм просторово-часовой нескінчености. Схоснуваный в ним остал сучасный, міграцийный 
модус однесіня до простору введеный в рамы міфічного колесистого часу. Вартат спомнути, што міграция, подорож, транспорт в незнане сильно зазначыли ся і в основным повыселенчым міфі, якій діял просторовом опозицийом сакрум-профанум. Міграция проходила не лем як eksodus, «судный ден»:

Ішли сме

того судного дня

в незнане

по части $з$ добытком

зо серцьом

на двоє розорваным (Trochanowska 1984).

Проходила тіж в другу страну по 1956 р., коли декотры ішли за закликом рідной землі, простору:

А ту - верх кождий кличе

отвертым крылом ліса (Graban 1995).

Актуальна достоменностьова міграция не послугує ся уж тым основным, фурт по части діючым міфом. Одчаруваный простір стабілізує достоменніст през рытуал, повторніст, циклічніст (припоминаючу колесо космічного часу) мігруваня/ вандруваня. Єднат він, лучыт вшыткы розшмарены лемківскы дияспоры і діє з натуры деєрархізуючы тото, што уж ся не даст утримати в выпрацуваным през повыселенчый реінвенцийный міф порядку. Розумленый прагматычні простір не ма сакрального центра. Незалежні бо од бездискусийні устабілізуваной фігуры Лемковины - лемківской землі - Гір, маючой глубоку символічну вартіст, реальне єй місце находит ся серед інчых просторів, де жыют Лемкы, а сама Лемковина заселена єст в головній мірі не Лемками.

Рытуальніст того мігруваня вызначена єст так часовом повторністю, регулярністю, як і святочным целебруваньом подорожы і єй цілого церемоніялу. Центральныма торжествами сут од понад тридцетьох років лемківскы Ватры. Колиси, в 80. роках, коли лемківску "розшарпану» достоменніст ісцілял реінвенцийный міф, была лем єдна Ватра, не могло быти іх більше, так як была лем єдна «свята» лемківска земля. Напрям праведной подорожы/ вандрівкы, был лем єден - доцентровый, 
выраженый символічном фразом «Піду за твоім теплом» (/м/ 1985, 1). Міф перестал діяти в тій основній формі, коли тоту єдину Ватру переняли (в 1989 р.) тоты, што проти іх домінациі і завлащаню лемківского символічного простору Ватра возникла. Товды наступило трісніня, сильна деструкция лемківского просторового міфу. Для ісціліня рытуалу автономіi, што го целебрувала Ватра, лемківскым огнискам, розпаляным од 1979 р. в Михалові (на землях выселіня Лемків) (Копча 2020), надана остала ранга Лемківской Ватры на чужыні. Конечна адже была модифікация реінвенцийного міфу, якій мал вызначыти і помочы поняти тоту зміну, усенсовнити новый міграцийный модель. Зміна мусіла доконати ся як суцо, вполни, найти/ створити текстуальну обудову, міфічну і прагматычну наррацию. Они тепер мусіли заістніти лем довєдна получены, бо сам міф не міг уж в тых часах і в тій ситуациі довершыти достоменностьовой переміны. Світ стал ся на тілько одчаруваный, же реінвенция годна была доконати ся лем синергійні, на основі двох модусів розумліня простору. Зацитую урывкы такой (свойой) реінвенцийной наррациі:

Чом іхам на Ватру на чужыну?

Гей, то не такє просте. Коли уж знала єм, же не годна буду без негатывных емоций (а старам ся іх елімінувати зо свого жытя) іздити на ждынскы Ватры, рішыла єм заперти свою візию Ватр на такым уявліню, якє лишыли мі «моі» Ватры - од чарнянскых зачынаючы, на бортнянскых кінчучы. Ватра то Ватра, скінчыла ся в 1989 р. і фертик (як бы повіла Желемова Пракседа). На Захід іхати єм ся не зберала. «Не по то моі няньове вертали з такым трудом в 1961 в Горы, жебы-м я тепер іздила на Захід» - думала єм вперто през долший час. Аж якоси, за намовом хыбаль Петра, спрібувала єм, здає ся в 1999 р. першыраз, поіхати в тоту сторону. 10 років по «моіх» Ватрах. Но і од той пробы ізджу уж што рока. Не хоче ся мі толчы таку долгу дорогу, в такій неінтересуючий для мене perioн, а іхам. Чом? Та причына єст неєдна. Най повіст Петро Трохановскій, чом того рока іхал такій фалат дорогы, жебы быти в Михалові пару годин, пошанувати што і кого належало і вертати як шалений зас понад 500 км, бо рано в суботу треба было быти в Креници. Так, наша Стоваришыньова імпреза, де бы не была, вымагат нашой участи. 3 пошаны для труду приятелів, для ідеі стрічы і для свідоцтва, же Горы не забывают про тых на Заході, же зме разом в нашій спільноті. Коли не маме можности провести тоту імпрезу в Горах, проведме єй бодай на Заході, але 
спільні, в кругу лемківскых спілідейників. Іхам на Ватру на чужыну, бо знам, же мя гын ждут. Не земля, котра єст мі чужа, лем люде, котры сут мі своі і справы, котры сут мі близкы (Дуць-Файфер 2004, 7).

Така адже ясна і проста выкладня - потверджыня і затверджыня на писмі зміны в однесіню до напряму рытуальной міграциі - вказує як діє і яку спосібніст надаваня спільнотового сенсу такій зміні має реінвенцийна наррация. Сохраніня в ній профанічного знакуваня чужой землі і выекспонуваня сакрум спільноты: люди і справ, усуват трісніня, неконсеквенцию, заперечыня, якє ся доконує в однесіню до усталеного повыселенчыма текстами міфу з просторовым сакрум-профанум.

Скомплікувала ся тіж по 1989 р. справа усвяченого напряму міграциі Захід - Горы/ чужына - Лемковина. Лемківскы тексты єднак фурт выконуют свою реінвенцийну місию, нарратывізуючы зміну і ісціляючы вшытко, што з єй причыны могло бы підважыти достоменностьовый міф спільноты. Для приміру:

«Горы нашы, горы нашы, горы нашы Карпаты»- заспівал Петро і повідат: Іхаме на Ватру! Призрил єм ся на нього. Смотрю - сыза по личку тече, голос ся трясе, цілий якісий змінений. I хоц горы не нашы, Ватра тіж уж іхнядумка в голові ся крутит - повісти-м того не годен. Петрусь бідненькый сызы повтерай. Та певні, же іхаме! Та треба жыти, а не сызити! (Годен си хлопец дашто іщы зробити).

Толкли сме ся потягом през піл Польщы, а друге піл толкло ся з нами. Ани єм не знал як Лемківска Ватра медженародных притігат. То нич, же ногы болят, коли Петро щестливий. 3 каждым кільометром ясніл Петрусь і здорівший ся робил. А в Горлицях з того щестя праві на люди ся шмарил, цілувати.

Всядиль чути: Ватра, Лемківска Ватра. в Ждыни пристерало през дорогу завісили. При вході, при сцені - всядиль: Лемківска Ватра. Та, Петре, - дома сме. В себе!

Сіл єм си пред сценом, же на выступы буду смотрил. [...] I так єм ся чудувал. [...] Што гын є пописане? Та вшыткы повідают - Лемківска Ватра. Но нибы єм ся кус вспокоіл. [...] На другій ден зачали ня уж єднак нервы брати. Бо повіджте сами - прикладово, купуєте си карту вступу на, дайме на то, фестиваль англицкой культуры, а они вам през два дни Бразилийчыків вказуют. Та бы сте ся не знервували?! Та до фраса! [...] Они вам вказуют Бразилийчыків 
як Англиків! [...] Та они з мене неусвідомленого і зацофаного роблят. А може іщы консервативного?! А бодай вас мало заднити! (Ксенич 2002, 452-453).

Каждый чытаючый Лемко (і не лем Лемко) зна, о якє вказуваня «Бразилийчыків» як «Англиків» на ждыньскій Ватрі ходит. Ясна єст реторика «неусвідомленого і зацофаного». Подібні як і дальша част тексту, де вказаны сут «больваны», што хцут на силу вопхати нарраторови фаны дружыны, з яком він николи не тримал. Тото вшытко было бы єднак лем менше або барже сугестывным описом стану зафальшуваня, якій здесакралізувал Лемківску Ватру і суть достоменностьовой вандрівкы гу ній, коли бы не симптоматычне для спільнотового міфу закінчыня:

А я ся взріл в його очы, я пребуджений, і на ня ганьба велика зышла. Же єм не чул, коли тоты больваны пришли, коли зо синього неба на нас попадали.

Але повідам ти, Петре, най си они перхают по своім синім ци інчым раю, але - повідам ти - они вылетят з мойого краю (Ксенич 2002, 454).

В тій наррациі нашло ся вшытко потрібне, жебы зрозуміти переміну і порадити си з ньом беручы одповідальніст за будуче приверніня стану правды і очыщыня простору з «больв (ф)анів» з чужыма фанами.

Вандрівка/ міграция стала ся рытуальным, достоменностьово конечным актом бытя в символічным часі там, де своі. Лемковина/ Горы в тій вандрівці надале остают уявным міфічным центром. Горнучы гев з ріжных части свойой дияспоры, Лемкы мают днес додаткову ціль - досвідчаня ступени деструкциі сакрального простору і етычный жест протиставліня ся тому.

Коли в фільмі крученым в 1993 р. (Ідеме, ідеме 1993) Петро Трохановскій - єден з головных творців лемківского реінвенцийного міфу выповіст опінію, же тепер вшытко, што автентычне на Ватрі односит ся до приізджаючых гев з любовю до рідной землі Лемків з Украіны, наступило дальше пересуніня/ перемішаня простору обнятого повыселенчом реінвенцийом. Видиме пак доконуючу ся по тым часі в наступных праві тридцетьох роках дальшу динаміку змін і надаваня ім спільнотового сенсу. Достеречы мож, же подібні як в цілым днешнім світі, міграцийна парадигма наганят достоменностьовы діяня. Єй колесистый характер єст своєрідністю, яку грунтувати треба в лемківскым міфічным механізмі утримуваня спільноты. Креуваня і целебруваня фурт новых свят і торжеств, якы сут претекстом до цикличного/ праздничного вандруваня медже землями 
лемківской дияспоры, днес стало ся формом просторовой достоменности пляново, хоц недокінце реальні выкорененой спільноты.

\section{Простір - язык - достоменніст}

Фактычна деструкция лемківского простору через выселіня заселяючой го спільноты, окрем вказаных горі реінвенцийных процесів, урухомила тіж інчы способы укріпляня глубоко нарушеной выкореніньом достоменности. Єдном 3 такых форм єст акцентуваня тых автоідентыфікацийных выріжників, што при полній деструкциі корінного простору стали ся основныма знаками ідентыфікуваня «своіх». Головным такым значником стала ся для розшмареных по «чужыні» Лемків своя бесіда. Взірцьовым текстом констатуючым тот факт єст верш - маніфест лемківского будителя Івана Русенкы:

Тож шануйме рідне слово

Од велика аж до мала,

Вшытко інче мы втратили.

Лем бесіда нам остала (Русенко 2010, 118).

Такє переконаня утырвалене єст серед Лемків до днес². Вартат адже пізрити, хоц бы лем загальні, на стан сохраніня ся лемківского языка залежні од простору, де по 1945/ 1947/ 1956 роках жыют Лемкы. Сконцентрую ся на сигнальным лем ${ }^{3}$ порівнаню деякых параметрів, вказуючых на сохраніня лемківского языка як рідного або домашнього в двох ріжных обшырях днешнього прожываня Лемків в Польщы - в Горах і на чужыні. Выходным пунктом порівнаня най будут статистычны даны.

Як відомо, в рамах акциі «Вісла» на понімецкы землі переселено бл. 32000 Лемків (Misiło 2013, 1013-1050). Розшмарено іх і піддано асиміляцийным діяням (Duć-Fajfer 2001). През цілый час комуністычной

2 Потвердила єм тото в проведеных в 2017 р. такой 50 інтервю з Лемками прожываючыма на Лемковині, на чужуні і на Украіні. Безпосередньо єм звідувала м.ін. о значыня языка для ix добростану і значыня языка для тырваня спільноты. На основі тых інтервю опубликувала єм м.ін. статю (С)тратити язык (Дуць-Файфер 2018).

3 Барже грунтовному порівнаню вартат посвятити окрему студию, де проведена буде тіж структурна аналіза змін в языку (бесідуваным і писаным) Лемків з Заходу і Гір. 
влады, постулюючой моноетнічніст польской державы, не проводжено повселюдных списів, в якых мож было деклярувати свою етнічну достоменніст. Серед офіцийні узнаных меншын не было Лемків, урядово остали они влучены до украіньской меншыны. Аж по 1989 р. Лемків зачали выміняти серед етнічных меншын (Hołuszko 1993; Berdychowska 1995). В статистыках хоснувано шацунковы даны, прото же першый спис, што брал до увагы етнічны/ народовы деклярациі, проведено аж в 2002 р. Подля того шацуваня Лемків в Польщы повинно быти 50-60 тис. (Hołuszko 1993). Шацувано тіж, же на обшыр Лемковины по 1956 p. вернуло даде з 7-10\% єй выселеных в 1947 р. жытели (Pudło 1992, 374). Можна адже додумувати ся, што не было то більше як 5 тис. осіб, а близко 50 тис. остало на західніх землях.

Повселюдный Спис 2002 зверифікувал тоты даны. Вказало ся, што лем 5863 польскых громадян задеклярувало лемківску народову приналежніст, в тым на західніх землях 4039, нецілых 10\% в однесіню до шацуваня, а на Лемковині 1621, даде з 30\% в однесіню до шацуваня (Deklarowana). Значыт то, же процес асиміляциі або страх перед выявліньом свойой етнічной приналежности, што вызули з родовой достоменности праві 90\% Лемків, были рішучо барже діючы на Заході, як на Лемковині. Подібні выглядают пропорциі в декляруваню хоснуваного дома языка. 5627 жыючых в Польщы осіб деклярувало хоснуваня лемківского языка, в тым на західніх землях 3687, а на Лемковині 1922 (Deklarowana). Мож достеречы гев симптоматычну тенденцию. 352 особы на Заході чули ся Лемками, але не хоснували лемківского языка дома. Наопак на Лемковині - 301 осіб, якы не деклярували ся як Лемкы, в домашніх контактах хоснувало лемківскій язык.

Наступный, проведеный в Польщы в 2011 р., повселюдный спис выказал 10531 здекляруваных Лемків, з чого 7450 походило з Заходу a 2544 з Лемковины (Ludność, 270). Як видно, пропорциі змінили ся кус на корыст Заходу. В 2002 р. были они 1:1,8, в 2011 р. - 1:2,9. Кєд деклярациі лемківской народовости повекшыли ся праві два раз, то не было такых результатів в обсягу языка. В 2011 р. лем 6279 осіб деклярувало лемківскій язык як домашній, значыт лем о 600 осіб більше як в 2002 р. в опрацуванях, што односят ся до спису з 2011 р., не подано выказів хоснуваного дома языка в окремых воєвідствах. Подля мене більшіст осіб, што деклярували лемківску народовіст, а не хоснуют дома лемківского языка, походит з воєвідств західньой Польщы. Коротко спрібую вказати, 
на якій основі (окрем статистык з 2002 р.) формую таку опінію. В тій ціли пересліджу корыстаня през Лемків з іх языковых прав.

Лемківскій язык был узнаный постановом Уставы 3 дня 6 січня 2005 р. о народовых і етнічных меншынах а тіж о регіональным языку (Ustawa) за єден з 15 меншыновых языків в Польщы. Так адже єст хороненый і може корыстати з языковых прав окрисленых в тій уставі як і в ратыфікуваній през Польщу в 2008 р. Європскій карті регіональных або меншыновых языків (Europejska karta). Єдным з основных прав єст право до вчыня рідного языка меншыны в школах. Вчыня ведене єст на внесок родичів і організує ся го товды, коли такых внесків єст в школі не менше як 7. Коли єст іх менше як 7, але принаймі 3, організує ся меджешкільне вчыня. Лемківского языка вчыт ся в школах од 1991 р., значыт введено го до шкіл іщы перед міністерияльным заряджыньом з 1992 р. окрисляючым принципы вчыня меншыновых языків. Што важне, першы школы, де введено такє вчыня, находили ся на Лемковині (Устя Горлицкє 1991; Крениця 1992; Розділя 1992). По парох роках зачало ся вчыня лемківского языка тіж на західніх землях. Не все єднак в офіцийній шкільній системі. Часом, як нп. в Лігници, діти і молодеж вчыли ся в світлици Стоваришыня Лемків. На днес лемківскій язык вченый єст як надобовязковый предмет маючый статус рідного языка лемківской меншыны, в вымірі 3 годин на тыжден. Вчыт ся го на рівни од передшколя до середньой школы. В шкільным році 2020-2021 подля офіцийных даных Мiністерства Едукациі і Наукы лемківского языка вчыло ся 309 учеників: 193 в 17 школах на Лемковині і 110 в 19 школах на західніх землях. Серед шкіл были по 2 передшколя на каждій 3 тых територий з 15 учениками на Лемковині і 21 учениками на Заході; 13 основных шкіл з 167 учениками на Лемковині і 17 основных шкіл 389 учениками на Заході; 1 загальноосвітный ліцей 38 учениками на Лемковині і 1 технікум з 3 учениками на Лемковині. Вчыло іх 19 учытели (Liczba uczniów).

Од 2014 р. лемківскы ученикы корыстают з можности здаваня матуры 3 рідного языка меншыны. Деклярациі зголошат 1-3 учеників на рік. До днес матуру з лемківского языка здавало 10 осіб - 6 осіб з західніх земель, 4 особы з Лемковины.

В роках 2001-2017 на Педагогічным Університеті в Кракові ведены были філологічны студиі, де могли ся вчыти будучы учытелі і інчы специялісты в просторі лемківского языка. На 14 студентів, што з походжыня были Лемками, 11 было з Лемковины, 3 з західніх земель. 
В рамах приналежных ім языковых прав Лемкы (головні Стоваришыня Лемківской Молодежы «Чуга») выстарали ся о поставліня в 9 селах на Лемковині інформацийных таблиц з назвом місцевости в лемківскым языку.

Іщы інчым польом порівнаня влияня простору на сохраніня і розвитя лемківского языка сут языковы практыкы. Гев достеречы мож скоро і поступенно розвиваючый ся процес загыбаня меджепоколіньового переказу лемківского языка, што рішат о узнаваню го за загроженый/ міцно загроженый (Wicherkiewicz 2011). На основі внутрішньой обсервациі, однотовую скоре темпо заниканя спонтанного хоснуваня выключні лемківского языка в безпосередніх товарискых бесідах в часі ріжного рода родинных і публичных стріч. Коли перед двадцетьома роками бабця бесідуюча до внучка по польскы чула ся змішана том ситуацийом в моій присутности (Лемківска Ватра на чужыні 2001), то днес зачудуваня і почутя великого одступства од нормы спричынят бесідуваня до внучка по лемківскы. Была єм свідком ситуациі, коли бабця барз зачудувана звідала свою сестру: «То Ты до внуків бесідуєш по лемківскы?» (родинна стріча, Лемковина 2015). Особливі в двох родах контактів видно значуче комунікацийне спольонізуваня: в меджепоколіньовых контактах - дідове/ родиче в однесіню до діти/ внуків менше як тридцетлітніх і в контактах в групах того самого поколіня - молодіжных і дітячых. В тым просторі обсервую тіж найбільшы ріжниці медже языковыма звыками серед Лемків в Горах і на чужыні. Коли бо в декляруваных языковых поставах неє ріжниці медже тыма середовисками - узнає ся язык за важный достоменностьовый вызначник, цінну вартіст і єдну з головных складовых добростану Лемків (Дуць-Файфер 2018), то в поведіню, головні на Заході, видно явну сперечніст в однесіню до декляраций. Молодеж з лемківского ансамблю «Ластівочка», хоц зна лемківскій язык (зо мном і з особами з Гір комунікує ся в тым языку), то в своім кругу бесідує по польскы.

Іщы гірша ситуация $є$ в обсягу писаного лемківского языка. На інтернетовых товариско-соспільных профілях, в коментарях, дискусиях рішучо домінує польскій язык або запис бесідуваного лемківского языка латинком. Не достерегла єм в тых практыках даякых сутьовых ріжниц медже середовиском західнім а Лемковином ани медже поколінями. Єднак вказати гев треба єден важный выняток. Єст група молодшых осіб (перед сороковым роком жытя), што послідовні не лем пише в лемківскым языку, але тіж ангажує ся в його ревіталізацию. Сут то основні 
особы, што вчыли ся лемківского языка ци то в школі, ци на лемківскій філологіi, тепер учытелі того языка, редакторы радия і порталю лем.ФМ, тлумаче, участникы ревіталізацийных проєктів, молоды дослідникы лемківского языка і літературы (Duć-Fajfer 2017). Рішуча більшіст з них походит з Лемковины, хоц декотры проєкты ведены сут спільні з особами зо Заходу, а на західніх землях тіж актывізує ся невелика групка амбітной молодежы, што старат ся быти консеквентні лемківскоязычна.

В тым контексті вартат тіж спомнути о ню спікерах (новых хоснувателях) в обсягу лемківского языка. Явліня ся новых хоснуватели і ревіталізаторів того языка єст ефектом одкрытых філологічных студий, на якых можна было придбати высоку языкову справніст і ангажувати ся в ревіталізацийны діяня (Duć-Fajfer 2021a).

\section{Внескы}

Прото, же поминене остало гев порівнаня деструкциі лемківского языка на рівни стосуваня корінных форм, внескы односити ся будут лем до поданых даных і сигналізуваных ріжниц в обсягу функціонуваня і кондициі лемківского языка в обох порівнуваных обшырях.

1. Зо списовых даных выникат, што заплянувана акультурация/ асиміляция Лемків барже єст заавансувана серед выселенців, што не вернули на Лемковину. Окрем того мож вывести внесок, же асиміляцийом обнята єст в найвысшій ступени база культуровой окремости - корінный язык і то головні на «чужыні», коли же ідеологічне/ декляратывне бытя Лемком може серед той самой групы в прихыльных соспільно-правных обставинах навет роснути.

2. В обсягу корыстаня з языковых прав тіж видима єст більша актывніст і мобілізация в середовисках Лемків, што вернули в Горы.

3. Языковы практыкы тіж выказуют більшу жывотніст рідного языка серед тых, што вернули і іх потомків.

Сесы даны і внескы сут згідны 3 вельома загальныма правилами в однесіню не лем до языковой жывотности, але тіж до дияспоры і выкореніня. Рох Суліма уважат, же люде без «матечників/ материків», выкорінены з рідного простору «то маса выдана на жертву ідеологіям, а рівночасно грунт, на якым клюют ся всякого рода тоталізмы. То люде без етосу» (Sulima 1989, 114, пер. О. Д-Ф). Перекладаючы то на вказану 
горі ситуацию мож речы, же лемківска достоменніст на Заході, не маючы оного просторового «гев/ ту» выражат ся барже ідеологічні. Прото могло повекшыти ся чысло народовых декляраций медже двома повселюдныма списами. Значучо єднак зменшыл ся статистычный параметер хоснуваня лемківского языка як домашнього. Язык формує достоменніст од внутри в симбіозі, в єдни з простором, з просторовым образом світа. Етнічны деклярациі то сфера ідеологіi. Бытя в языку і через язык, то сфера жытя. Незалежні од того, же вертаючы в Горы Лемкы находят ся реальні в дияспорийній ситуациі (абсолютна більшіст іх рідной териториі заселена єст новыма осадниками, серед якых Лемкы тепер то розшмареный маленькій процент населіня), земля, до якой вертают, єст іх «матечником/ материком», корінным простором, што давал і дає жытя тіж іх языкови. Єднак з досліджынь і обсервациі видно, што не єст то старчаюча охорона і сила для языка. Конечна єст інституцийна підпора, з яком треба бы встигнути закля цілком ослабне меджепоколіньове переказуваня языка. Тіж і в тій сфері більшу мобільніст выказуют середовиска з Лемковины, Захід єднак долучат до них, не устают спільны діяня. Можна прото твердити, же вкореніня, навет перерване, дияспорийне, базуюче на просторовым чыннику, ма глубоку культурово-психічну потенцию.

\section{Бібліографія}

Антонич, Богдан Ігор. 1967. «Село». В: Пісня про незнищенність матерії. Поезії. Ред. Дмитро Павличко, 160. Київ: Радянський письменник.

Астрябъ, Матвъй. 1871. «Ко̄лька сло̄въ о лемкоิвско̄й бесъдъ». Учитель, ч. 43-52.

Горощак, Іван. 2002. «Прощай моя Лемковино». В: Ци то лем туга, ии надія. Антологія повыселенчой лемківской літературы. Ред. Олена Дуць-Файфер, 118-124. Лігниця: Стоваришыня Лемків.

Грабан, Володислав. 2002. «Велия». В: Ци то лем туга, ии надія. Антололія повыселенчой лемківской літературы. Ред. Олена Дуць-Файфер, 428-429. Лігниця: Стоваришыня Лемків.

Дуць-Файфер, Олена. 2004. «Ватра - што она значыт днес». Бесіда, ч. 5 (80): 7-9. Дуць-Файфер, Олена. 2017. «А Вісла дале пльне Петра Мурянкы - автобіографія як реінвенцийний міф». Річник Руской Бурсы, ч. 13: 149-167.

Дуць-Файфер, Олена. 2018. «(С)тратити язык што то значыт, што то творит? Лемківскє выгнаня з языка». В: 20 років высокошкольской русиністікы на Словакіі. Зборник ребератів з меджінародной научной конберениї. Ред. Kvetoslava Koporova, 67-81. Пряшів: Пряшівска універзіта. 
Жылич, Нестор. 2002. «Нашы горы». В: Ци то тем туга, ии надія. Антологія повыселенчой лемківской тітературы. Ред. Олена Дуць-Файфер, 98-99. Лігниця: Стоваришыня Лемків.

Копча, Андрий. 2020. «40 михалівскых Огниск і Ватр». Лемківскій Річник: 61-98.

Ксенич, Павел. 2002. «Петро і Ватра». В: Ци то лем туга, изи надія. Антололія повыселенчой лемківской літературы. Ред. Олена Дуць-Файфер, 452-454. Лігниця: Стоваришыня Лемків.

/м/ [Мурянка]. 1985. «Піду за твоім теплом». Голос Bampы: 1.

Мурянка, Петро. 1989. «Humanitas». B: Petro Murianka, Jak sokół wodę z kamienia/ Як сокіл воды на камени. Пер. Барбара Дохналик, 6. Warszawa: Iskry.

Полянскій, Петръ. 1888. Карпатскіи Новелли, т. I-II. Leipzig: Wolfgang Gerhard.

Русенко, Іван. 1945. «Лемковина». В: Наша Книжка. Ред. Димитрий Ф. Вислоцкій, 147-148. Юнкерс. Н. Й.: Лемко-Союз.

Русенко, Іван. 2002. «Тепер на Лемковині». В: Ци то лем туга, изи надія. Антолоsія повыселенчой лемківской літературы. Ред. Олена Дуць-Файфер, 49. Лігниця: Стоваришыня Лемків.

Русенко, Іван. 2010. «Рік 1945». В: Русенко, Выбране. Ред. Петро Трохановскій, 115118. Крениця-Лігниця: Стоваришыня Лемків.

Собин, Меланія. 2002. «Лемковина». В: Ци то лем туга, ии надія. Антологія повыселенчой лемківской літературы. Ред. Олена Дуць-Файфер, 128-129. Лігниця: Стоваришыня Лемків.

Сук, Лука. 2009. «Чмель. Ту останеме на долгы рокы». Бесіда, ч. 5 (110): 20-21.

Тороньскій, Алексій. 1862. «Ганця. Повъсть зъ житья Подбескидского народа (Лемковъ)». Галичанинъ. Литературый сборникъ: 57-98.

Bartmiński, Jerzy. 1988. «„Niebo się wstydzi”. Wokół ludowego pojmowania ładu świata». B: Kultura - literatura - folklor. Ред. Marek Graszewicz, Jacek Kolbuszewski, 96-106. Warszawa: Ludowa Spółdzielnia Wydawnicza.

Bokszański, Zbigniew. 1999. «Tożsamość narodowa w perspektywie transformacji systemowej». B: Imponderabilia wielkiej zmiany. Mentalność, wartości i więzi społeczne czasów transformacji. Ред. Piotr Sztompka, 291-307. Warszawa-Kraków: Wydawnictwo Naukowe PWN.

Buczyńska-Garewicz. 2006. Miejsca, strony, okolice. Przyczynek do fenomenologii przestrzeni. Kraków: Universitas.

Deklarowana narodowość oraz język używany w kontaktach domowych $w$ Narodowym Spisie Powszechnym Ludności i Mieszkań 2002. Доступ: 2.10.2021. https://stat.gov.pl/ spisy-powszechne/narodowe-spisy-powszechne/narodowy-spis-powszechny-2002/ wyniki-narodowego-spisu-powszechnego-2002-narodowosci-oraz-jezyka/.

Duć-Fajfer, Helena. 2001. «Być Łemkiem w PRL-u». Zeszyty Naukowe Uniwersytetu Jagiellońskiego, MCCXLVII = Prace Etnograficzne 36: 141-172.

Duć-Fajfer, Helena. 2017. «Język, literatura, tożsamość: dyskurs współczesnej łemkowskości». В: Świat za tekstem. Ред. Jolanta Lubocha-Kruglik, Oksana Małysa, 133-150. Katowice: Wydawnictwo Naukowe „Śląsk”. 
Duć-Fajfer, Ołena. 2021a. «Immersive Łemko Ethnophilology». B: Revitalizing Endangered Languages. A Practical Guide. Ред. Justyna Olko, Julia Sallabank, 261-262. New York: Cambridge University Press.

Europejska karta języków regionalnych lub mniejszościowych. 1992. Доступ: 2.10.2021. http://isap.sejm.gov.pl/isap.nsf/download.xsp/WDU20091371121/O/D20091121.pdf.

Graban, Władysław. 1995. «До выгнаных». B: Władysław Graban. Rozsypane pejzaże, 55. Krynica: Towarzystwo na Rzecz Rozwoju Kultury Łemkowskiej w Zyndranowej.

Hołuszko, Marek. 1993. «Mniejszości narodowe i etniczne w Polsce». Społeczeństwo Otwarte, ч. 2: 1-16.

Ideme, ideme, drażki ne znajeme... (reportaż). 1993. Реж. Waldemar Janda, Krzysztof Krzyżanowski. Kraków: Telewizja Polska.

Liczba uczniów uczących się języków mniejszości narodowych, etnicznych i języka regionalnego $w$ podziale na język nauczania, typ szkoły $i$ województwa $w$ roku szkolnym 2020/2021. 2021. Доступ: 2.10.2021. https://dane.gov.pl/pl/dataset/276,nauka-jezy kow-mniejszosci-narodowych-etnicznych-i-jezyka-pegionalnego/resource/31297/ table? page $=1 \&$ per_page $=20 \& \mathrm{q}=\&$ sort $=$.

Lompart, Aleksandra, ред. 2010. Jednostka zakorzeniona? Wykorzeniona? = Studia i analizy Instytutu Socjologii UW. Warszawa: Wydawnictwo Uniwersytetu Warszawskiego.

Berdychowska, Bogusława, ред. 1995. Mniejszości narodowe w Polsce. Informator 1994. Warszawa: Wydawnictwo Sejmowe.

Misiło, Eugeniusz, ред. 2013. Repatriacja czy deportacja. Dokumenty. Том 1-2. Warszawa: Archiwum Ukraińskie.

Murianka, Petro. 2007. A Wisła dalej płynie. Krynica-Legnica: Stowarzyszenie Łemków.

Pudło, Kazimierz. 1992. «Dzieje Łemków po drugiej wojnie światowej». B: Łemkowie w historii i kulturze Karpat, Том. 1. Ред. Jerzy Czajkowski, 351-385. Rzeszów: Editions Spotkania.

Smith, Anthony. 1991. National Identity. London: University of Nevada Press.

Trochanowska, Stefania. 1984. «Судний ден». B: Stefania Trochanowska. Potem, teraz, przedtem, 11. Nowy Sącz: Sądecka Oficyna Wydawnicza.

Trochanowski, Piotr. 1992. Słowo Łemka o sobie i swoim narodzie. Wznowienie z 1987 roku: Regiony nr 2-4 (1987). Legnica: Стоваришыня Лемків.

Tuan, Yi-Fu. 1977. Space and Place. Minneapolis: University of Minnesota Press.

Tuan, Yi-Fu. 1987. Przestrzeń i miejsce. Пep. Agnieszka Morawińska. Warszawa: Państwowy Instytut Wydawniczy.

Ustawa $z$ dnia 6 stycznia 2005 r. o mniejszościach narodowych i etnicznych oraz o języku regionalnym. Доступ: 2.10.2021. http://isap.sejm.gov.pl/isap.nsf/download.xsp/WDU20050170141/U/D20050141Lj.pdf.

Wicherkiewicz, Tomasz. 2011. Sytuacja językowa Łemków - stan, zagrożenia i postulaty. Доступ: 2.10.2021. http://www.beskid-niski.pl/forum/viewtopic.php?t=3906. 